\title{
Perioperative Infection Prophylaxis and Risk Factor Impact in Colon Surgery
}

\author{
H.G. Rau ${ }^{a} \quad$ U. Mittelkötter ${ }^{b} \quad$ A. Zimmermann ${ }^{a} \quad$ A. Lachmann ${ }^{c}$ \\ L. Köhler ${ }^{d}$ K.H. Kullmann ${ }^{\mathrm{e}}$ \\ aDepartment of Surgery, Grosshadern Hospital, Ludwig Maximilian University, Munich, \\ bDepartment of Surgery, Würzburg University Hospital, Würzburg, ' Department of Surgery, \\ Auguste-Viktoria Hospital, Berlin, dDepartment of Surgery, Hospital St. Elisabeth, \\ Grevenbroich, eHoffmann-La Roche AG, Grenzach-Wyhlen, Germany
}

\section{Key Words}

Colon resection - Antibiotic prophylaxis . Ceftriaxone $\cdot$ Cost-benefit analysis $\cdot$ Risk factors $\cdot$ Postoperative infection . Cephalosporins · Penicillins

\begin{abstract}
Background: A prospective observational study was undertaken in 2,481 patients undergoing elective colon resection in 114 German centers to identify optimal drug and dosing modalities and risk factors for postoperative infection. Methods: Patients were pair matched using six risk factors and divided into 672 pairs (ceftriaxone vs. other cephalosporins, group A) and 400 pairs (ceftriaxone vs. penicillins, group B). End points were local and systemic postoperative infection and cost effectiveness. Results: Local infection rates were 6.0 versus $6.5 \%$ (group
\end{abstract}

\begin{tabular}{ll}
\hline KARGER & ( ) 2000 S. Karger AG, Basel \\
Fax +41 61 306 12 34 & \\
$\begin{array}{l}\text { E-Mail karger@karger.ch } \\
\text { www.karger.com }\end{array}$ & $\begin{array}{l}\text { Accessible online at: } \\
\text { www.karger.com/journals/che }\end{array}$
\end{tabular}

A) and 4.0 versus $10.5 \%$ (group B); systemic infection rates in groups $A$ and $B$ were 4.9 versus $6.3 \%$ and 3.3 versus $10.5 \%$, respectively. Ceftriaxone was more effective than penicillins overall (6.8 vs. $17.8 \%, \mathrm{p}<0.001)$. Length of postoperative hospital stay was 16.2 versus 16.9 days (group $A$ ) and 15.8 versus 17.6 days (group B). Of the six risk factors, age and concomitant disease were significant for systemic infection, and blood loss, rectum resection and immunosuppressive therapy were significant for local infection. Penicillin was a risk factor compared to ceftriaxone ( $p<0.0001$ ). Ceftriaxone saved $€ 160.7$ versus other cephalosporins and $€ 416.2$ versus penicillins. Conclusion: Clinical and microbiological efficacy are responsible for the cost effectiveness of ceftriaxone for perioperative prophylaxis in colorectal surgery.

Copyright $@ 2000$ S. Karger AG, Basel

PD Dr. H.G. Rau

Chirurgische Klinik und Poliklinik der Ludwig-Maximilians-Universität D-81377 München (Germany)

Tel. +49 8970953560 , Fax +498970958894

E-Mail hrau@gch.med.uni-muenchen.de 
Table 2. Group distribution (\%) of main risk factor matching criteria

\begin{tabular}{lcc}
\hline Criterion & $\begin{array}{l}\text { Group A } \\
(672 \text { pairs })\end{array}$ & $\begin{array}{l}\text { Group B } \\
\text { (400 pairs) }\end{array}$ \\
\hline Age $>65$ years & 58.3 & 56.3 \\
Operation duration $>2 \mathrm{~h}$ & 65.3 & 58.3 \\
Blood loss $>$ 3 red cell concentrates & 1.8 & 3.8 \\
Colon + rectum resection & 20.1 & 19.3 \\
Preexisting diabetes mellitus, hepatic, renal or airways disease & 33.4 & 37.3 \\
Immunosuppressive therapy or radiation & 3.6 & 1.8 \\
\hline
\end{tabular}

Table 3. Group demographics, preoperative diagnosis and concomitant disease

\begin{tabular}{|c|c|c|c|c|}
\hline \multirow[t]{2}{*}{ Parameter } & \multicolumn{2}{|c|}{ Group A (672 pairs) } & \multicolumn{2}{|c|}{ Group B (400 pairs) } \\
\hline & ceftriaxone & $\begin{array}{l}\text { other } \\
\text { cephalosporins }\end{array}$ & ceftriaxone & penicillins \\
\hline Age, years & 65.9 & 66.1 & 65.4 & 66.0 \\
\hline Height, cm & 168.5 & 167.7 & 168.7 & 169.0 \\
\hline Weight, kg & 72.6 & 72.1 & 73.0 & 73.9 \\
\hline Sex (male), $\%$ & 49.1 & 45.2 & 46.8 & 48.0 \\
\hline Colon carcinoma, $\%$ & 65.8 & 69.9 & 66.0 & 73.0 \\
\hline Diverticulitis, $\%$ & 18.6 & 14.7 & 18.3 & 15.5 \\
\hline Crohn's disease, $\%$ & 1.8 & 0.9 & 1.5 & 1.3 \\
\hline Ulcerative colitis, $\%$ & 1.9 & 0.9 & 2.5 & 0.5 \\
\hline Preexisting ileus/severe intestinal stenosis, $\%$ & 15.0 & 12.5 & 14.8 & 11.8 \\
\hline Preexisting colostomy, $\%$ & 7.1 & 5.4 & 6.5 & 2.8 \\
\hline Prior abdominal surgery, $\%$ & 4.8 & 4.3 & 3.8 & 3.0 \\
\hline Concomitant disease, $\%$ & 63.1 & 64.1 & 68.3 & 64.0 \\
\hline Cardiovascular, \% & 46.4 & 43.5 & 50.0 & 46.0 \\
\hline Diabetes mellitus, $\%$ & 12.4 & 13.9 & 13.0 & 16.0 \\
\hline Chronic airways, $\%$ & 11.9 & 9.8 & 15.8 & 10.0 \\
\hline Obesity, \% & 10.9 & 11.3 & 14.0 & 13.0 \\
\hline
\end{tabular}

cell concentrates); colon resection plus rectum resection (yes/no); age (< or $>65$ years); preexisting diabetes mellitus, hepatic, renal or airway disease (yes/no); immunosuppressive therapy (e.g. steroids) or radiation (yes/no). Patients paired for all six criteria were assigned to group A (ceftriaxone vs. other cephalosporins) or group B (ceftriaxone vs. penicillin).

Risk analysis to validate the matching criteria was performed in the total evaluable population $(n=2,481)$ after excluding protocol violators $(n=32)$. Antibiotic regimes were tested in this population for their impact

Infection Prophylaxis and Risk Factors in Colon Surgery on postoperative infection rates and the results were expressed as odds ratios (OR). A significance level of $\mathrm{p}<0.05$ was used in all tests.

\section{Patient Groups}

Group A comprised 1,344 patients and group B 800 patients (table 1). The distribution of the six matching risk factors is shown in table 2. Groups A and $\mathrm{B}$ did not differ in respect to demographics, preoperative diagnosis, risk factors or type of colon resection (tables 3-5). 
Table 4. Type of colon resection (\%) in groups A and B

\begin{tabular}{|c|c|c|c|c|}
\hline \multirow[t]{2}{*}{ Colon resection } & \multicolumn{2}{|c|}{ Group A (672 pairs) } & \multicolumn{2}{|c|}{ Group B (400 pairs) } \\
\hline & ceftriaxone & $\begin{array}{l}\text { other } \\
\text { cephalosporins }\end{array}$ & ceftriaxone & penicillins \\
\hline Cecum and ascending colon & 23.5 & 25.6 & 24.0 & 25.0 \\
\hline Transverse colon & 6.6 & 4.9 & 5.5 & 8.0 \\
\hline Descending colon & 14.9 & 13.2 & 11.5 & 11.5 \\
\hline Sigmoid colon & 32.9 & 39.0 & 37.3 & 37.8 \\
\hline With protective colostomy/ileostomy & 8.1 & 9.9 & 8.1 & 8.6 \\
\hline Rectum (deep anastomosis) ${ }^{1}$ & 20.1 & 20.1 & 19.3 & 19.3 \\
\hline With protective colostomy/ileostomy & 17.8 & 23.0 & 19.5 & 15.6 \\
\hline Other colon surgery & 16.5 & 16.1 & 17.0 & 12.3 \\
\hline Creation of colostomy & 8.9 & 7.7 & 7.8 & 7.8 \\
\hline Colostomy reversal & 5.8 & 3.4 & 4.8 & 2.3 \\
\hline
\end{tabular}

1 Matching criterion.

Table 5. Nonmatching operative risk factors in groups A and B

\begin{tabular}{|c|c|c|c|c|}
\hline \multirow[t]{2}{*}{ Risk factor } & \multicolumn{2}{|c|}{ Group A (672 pairs) } & \multicolumn{2}{|c|}{ Group B (400 pairs) } \\
\hline & ceftriaxone & $\begin{array}{l}\text { other } \\
\text { cephalosporins }\end{array}$ & ceftriaxone & penicillins \\
\hline Operation duration, $\min$ & 153 & 156 & 147 & 148 \\
\hline Blood loss, $\mathrm{ml}$ & 423 & 467 & 436 & 460 \\
\hline Clean bowel, $\%$ & 94.5 & 91.2 & 91.8 & 92.3 \\
\hline Intraoperative bowel irrigation, $\%$ & 4.6 & 4.6 & 4.3 & 5.8 \\
\hline Stapler anastomosis, $\%$ & 34.1 & 39.1 & 36.8 & 27.5 \\
\hline Abdominal drainage, $\%$ & 86.9 & 89.6 & 87.3 & 91.8 \\
\hline
\end{tabular}

Dosage and Concomitant Prophylaxis

Antibiotics and administration modalities are shown in tables 6 and 7. Ceftriaxone was administered in $90 \%$ of cases as a single preoperative 2-gram dose. The average duration of prophylaxis with the other beta-lactams was 2-3 days. Only amoxicillin/clavulanic acid was administered for a shorter period, i.e. 1.36 days. In group A, concomitant metronidazole was given to 62.2 and $80.5 \%$ of ceftriaxone and other cephalosporin patients, respectively, and in group B, to 66.3 and $51.0 \%$ of ceftriaxone and penicillin patients, respectively. Concomitant gentamicin was given to
$4.9 \%$ of other cephalosporin patients and $1 \%$ of penicillin patients. Other concomitant antibiotic therapy was given to $1.7 \%$ of ceftriaxone patients and $0.6 \%$ of other cephalosporin patients in group A and $0.8 \%$ of both subgroups in group $\mathrm{B}$.

\section{Standard Microbiology}

This was performed intraoperatively for suspected infection and in postoperative infections. 
Table 6. Antibiotic dosage and administration modalities in group A
Table 7. Antibiotic dosage and administration modalities in group B

\begin{tabular}{lllll}
\hline Antibiotic & Schedule & $\begin{array}{l}\text { Frequency } \\
\text { of use, } \%\end{array}$ & $\begin{array}{l}\text { Mean } \\
\text { dose, } \mathrm{g}\end{array}$ & $\begin{array}{l}\text { Duration } \\
\text { days }\end{array}$ \\
\hline Ceftriaxone & & & 1.99 & 1.49 \\
\hline Cefotiam & $1 \times 2 \mathrm{~g}$ & 90.3 & & \\
& $1 \times 2 \mathrm{~g}$ & 67.4 & 2.90 & 2.33 \\
& $2 \times 2 \mathrm{~g}$ & 11.1 & & \\
& $3 \times 2 \mathrm{~g}$ & 13.3 & & \\
\hline Cefuroxime & & & 2.49 & 2.41 \\
& $1 \times 1.5 \mathrm{~g}$ & 53.1 & & \\
& $2 \times 1.5 \mathrm{~g}$ & 12.6 & & \\
& $3 \times 1.5 \mathrm{~g}$ & 20.0 & & \\
\hline Cefazolin & & & 3.25 & \\
& $1 \times 2 \mathrm{~g}$ & 58.5 & & \\
& $2 \times 2 \mathrm{~g}$ & 20.8 & & \\
& $3 \times 2 \mathrm{~g}$ & 20.8 & & \\
& & & &
\end{tabular}

\begin{tabular}{lclll}
\hline Antibiotic & Schedule & $\begin{array}{l}\text { Frequency } \\
\text { of use, } \%\end{array}$ & $\begin{array}{l}\text { Mean } \\
\text { dose, } \mathrm{g}\end{array}$ & $\begin{array}{l}\text { Duration } \\
\text { days }\end{array}$ \\
\hline Ceftriaxone & $1 \times 2 \mathrm{~g}$ & 89.3 & 2.00 & 1.48 \\
& & & 4.77 & 2.17 \\
\hline Mezlocillin & $1 \times 2 \mathrm{~g}$ & 25.6 & & \\
& $1 \times 4 \mathrm{~g}$ & 25.6 & & \\
& $3 \times 2 \mathrm{~g}$ & 31.0 & & \\
& & & 2.49 & 1.36 \\
& $1 \times 2.2 \mathrm{~g}$ & 74.5 & & \\
\hline Amoxicillin/clavulanic acid & 9.4 & & \\
& & & \\
& & & \\
\hline Ampicillin/sulbactam & & & \\
$1 \times 3 \mathrm{~g}$ & 51.0 & & \\
$3 \times 3 \mathrm{~g}$ & 26.0 & &
\end{tabular}

\section{Results}

\section{Clinical Results}

The rates of infectious complications in the first 10 postoperative days were $10.0 \%$ with ceftriaxone versus $10.9 \%$ with other cephalo- sporins in group A, and 6.8 versus $17.8 \%$ with ceftriaxone versus penicillin in group B (table 8). Physicians' impressions rated prophylaxis effective in 92.4 and $83.8 \%$ of ceftriaxone and other cephalosporin patients in group A, and in 91.8 and $83.3 \%$ of ceftriaxone and

Chemotherapy 2000;46:353-363 
Table 8. Infectious complications (n) in the first 10 postoperative days

\begin{tabular}{|c|c|c|c|c|}
\hline \multirow[t]{2}{*}{ Complication } & \multicolumn{2}{|c|}{ Group A (672 pairs) } & \multicolumn{2}{|c|}{ Group B (400 pairs) } \\
\hline & ceftriaxone & $\begin{array}{l}\text { other } \\
\text { cephalosporins }\end{array}$ & ceftriaxone & penicillins \\
\hline \multicolumn{5}{|l|}{ Local complications } \\
\hline Suppurating wound & 22 & 20 & 11 & 18 \\
\hline Abscess & 7 & 11 & 2 & 9 \\
\hline Peritonitis & 2 & 3 & 0 & 4 \\
\hline Suture failure & 9 & 10 & 3 & 11 \\
\hline Total local complications & $40(6.0)$ & $44(6.5)$ & $16(4.0)$ & $42(10.5)$ \\
\hline \multicolumn{5}{|l|}{ Systemic infections } \\
\hline Pneumonia & 7 & 16 & 6 & 14 \\
\hline Other respiratory tract infections & 3 & 3 & 1 & 1 \\
\hline Urinary tract infection & 17 & 18 & 4 & 18 \\
\hline Venous catheter infection & 5 & 3 & 2 & 6 \\
\hline Sepsis & 1 & 1 & 0 & 3 \\
\hline Other systemic infection & 0 & 1 & 0 & 0 \\
\hline Total systemic infections & $33(4.9)$ & $42(6.3)$ & $13(3.3)$ & $42(10.5)$ \\
\hline Total infection rate & $67(10.0)$ & $73(10.9)$ & $27(6.8)$ & $71(17.8)^{*}$ \\
\hline
\end{tabular}

Figures in parentheses represent percentages. $* p<0.001$ for ceftriaxone versus penicillin.

penicillin patients in group B. Adverse events (whether related to antibiotics or not) occurred in fewer than 5\% of cases: 4.5 and $3.9 \%$ in the ceftriaxone and other cephalosporin subgroups, respectively, in group A, and 4.3 and $3.0 \%$ in the ceftriaxone and penicillin subgroups, respectively, in group B. There were 0 and 4 postoperative inpatient deaths in the ceftriaxone and other cephalosporin subgroups, and 1 and 2 in the ceftriaxone and penicillin subgroups.

\section{Microbiology}

Postoperative pathogens were markedly fewer with ceftriaxone compared to other antibiotics: 23 versus 45 gram-positive isolates, and 28 versus 58 gram-negative isolates, respectively (table 9). Gram-negative infection rates were lower with ceftriaxone than with other cephalosporins. The rates of both gramnegative and gram-positive infections were lower with ceftriaxone than with penicillin. Pathogen distribution in postoperative wound and airway infections (table 10) showed a majority of Escherichia coli and other Enterobacteriaceae, followed by staphylococci, enterococci and Pseudomonas spp. No airway or wound infections due to Pseudomonas spp. occurred with ceftriaxone. There were also fewer enterococcal and staphylococcal wound infections with ceftriaxone than with penicillin ( 1 vs. 4 , and 4 vs. 9, respectively).

\section{Risk Analysis}

Rectum resection $(\mathrm{OR}=1.55, \mathrm{p}=0.022)$ and concomitant disease $(\mathrm{OR}=1.65, \mathrm{p}=$ $0.0001)$ were prognostically significant risk 
Table 9. Postoperative gram-positive/gram-negative infections (n)

\begin{tabular}{|c|c|c|c|c|}
\hline \multirow[t]{2}{*}{ Sample site } & \multicolumn{2}{|c|}{ Group A (672 pairs) } & \multicolumn{2}{|c|}{ Group B (400 pairs) } \\
\hline & $\begin{array}{l}\text { ceftri- } \\
\text { axone }\end{array}$ & $\begin{array}{l}\text { other } \\
\text { cephalosporins }\end{array}$ & $\begin{array}{l}\text { ceftri- } \\
\text { axone }\end{array}$ & $\begin{array}{l}\text { peni- } \\
\text { cillins }\end{array}$ \\
\hline Airways & $1 / 2$ & $1 / 6$ & $0 / 0$ & $3 / 2$ \\
\hline Blood & $0 / 2$ & $0 / 0$ & $0 / 1$ & $2 / 1$ \\
\hline Wound & $12 / 11$ & $13 / 21$ & $6 / 8$ & $13 / 14$ \\
\hline Urine & $3 / 2$ & $4 / 6$ & $1 / 2$ & $9 / 8$ \\
\hline $\mathrm{n}_{\text {total }}$ & $16 / 17$ & $18 / 33$ & $7 / 11$ & $27 / 25$ \\
\hline Total pathogens $(\mathrm{n}=154)$ & 33 & 51 & 18 & 52 \\
\hline
\end{tabular}

Table 10. Pathogen distribution (n) in postoperative wound and respiratory tract infections

\begin{tabular}{|c|c|c|c|c|}
\hline \multirow[t]{2}{*}{ Isolate } & \multicolumn{2}{|c|}{ Group A (672 pairs) } & \multicolumn{2}{|c|}{ Group B (400 pairs) } \\
\hline & $\begin{array}{l}\text { ceftri- } \\
\text { axone }\end{array}$ & $\begin{array}{l}\text { other } \\
\text { cephalosporins }\end{array}$ & $\begin{array}{l}\text { ceftri- } \\
\text { axone }\end{array}$ & $\begin{array}{l}\text { peni- } \\
\text { cillins }\end{array}$ \\
\hline \multicolumn{5}{|l|}{ Respiratory tract } \\
\hline Enterobacteriaceae & 2 & 1 & 0 & 2 \\
\hline Pseudomonas spp. & 0 & 4 & 0 & 0 \\
\hline Other & 1 & 2 & 0 & 3 \\
\hline \multicolumn{5}{|l|}{ Wound } \\
\hline Staphylococci & 3 & 3 & 4 & 9 \\
\hline Enterococci & 7 & 9 & 1 & 4 \\
\hline Escherichia coli & 5 & 10 & 3 & 9 \\
\hline Other Enterobacteriaceae & 3 & 4 & 3 & 2 \\
\hline Pseudomonas spp. & 0 & 4 & 0 & 1 \\
\hline Bacteroides spp. & 3 & 2 & 2 & 2 \\
\hline Other bacteria & 2 & 2 & 1 & 0 \\
\hline
\end{tabular}

factors for postoperative infection (table 11). Further analysis showed age and concomitant disease to be significant risk factors for systemic complications, while blood loss, rectum resection and immunosuppressive therapy were significant risk factors for local complications. Operation duration of more than $2 \mathrm{~h}$ was associated with a nonsignificant increase in postoperative complications (table 12). Five of the six matching criteria significantly impacted on the postoperative infection rate, thereby confirming their suitability for unbiased patient pairing.

Testing antibiotic regimes for an impact on postoperative infection in the total population showed penicillin to be a significant risk factor compared to ceftriaxone $(\mathrm{OR}=2.18, \mathrm{p}<$ 0.0001 ), and prophylaxis without metronidazole for anaerobe cover $(\mathrm{OR}=1.79, \mathrm{p}<$ $0.0001)$. Analysis of the individual antibiotic 
Table 11. Risk factors for postoperative infection

\begin{tabular}{lccl}
\hline Risk factor & Infection, $\%$ & OR & $\mathrm{p}$ \\
\hline Age $\leq />65$ years & $10.7 / 12.1$ & 1.15 & 0.265 \\
Operation duration $\leq />2 \mathrm{~h}$ & $10.0 / 12.4$ & 1.28 & 0.063 \\
Blood loss $\leq />$ 3 red cell concentrates & $11.3 / 17.6$ & 1.70 & 0.064 \\
Colon + rectum resection (no/yes) & $10.5 / 15.4$ & 1.55 & 0.022 \\
Concomitant disease (no/yes) & $15.6 / 10.0$ & 1.65 & 0.0001 \\
Immunosuppressive therapy (no/yes) & $11.2 / 17.1$ & 1.63 & 0.063 \\
Ceftriaxone/other cephalosporins & $9.3 / 11.0$ & 1.21 & 0.214 \\
Ceftriaxone/penicillin & $11.0 / 18.3$ & 1.80 & 0.0005 \\
Ceftriaxone +/- metronidazole & $7.7 / 11.8$ & 1.61 & 0.012 \\
Other cephalosporins +/- metronidazole & $9.6 / 17.0$ & 1.93 & 0.014 \\
Penicillin +/- metronidazole & $13.8 / 22.7$ & 1.84 & 0.013 \\
\hline
\end{tabular}

Table 12. Risk factors for local and systemic postoperative infection

\begin{tabular}{llllr}
\hline Risk factor & $\begin{array}{l}\text { Local } \\
\text { infection, } \%\end{array}$ & $\mathrm{p}$ & \multicolumn{2}{l}{$\begin{array}{l}\text { Systemic } \\
\text { infection, } \%\end{array}$} \\
\hline Age $\leq />65$ years & $6.8 / 5.7$ & 0.239 & $4.5 / 6.8$ & 0.014 \\
Operation duration $\leq />2 \mathrm{~h}$ & $5.2 / 6.9$ & 0.082 & $5.1 / 6.2$ & 0.222 \\
Blood loss $\leq />$ 3 red cell concentrates & $5.9 / 14.3$ & 0.001 & $5.8 / 5.5$ & 0.908 \\
Colon + rectum resection (no/yes) & $5.6 / 8.8$ & 0.007 & $5.5 / 7.0$ & 0.185 \\
Concomitant disease (no/yes) & $5.8 / 7.3$ & 0.199 & $4.5 / 9.3$ & $<0.001$ \\
Immunosuppressive therapy (no/yes) & $5.9 / 13.3$ & 0.002 & $5.8 / 5.7$ & 0.982 \\
\hline
\end{tabular}

Table 13. Main postoperative cost factors

\begin{tabular}{|c|c|c|c|c|}
\hline \multirow[t]{2}{*}{ Factor } & \multicolumn{2}{|c|}{ Group A (672 pairs) } & \multicolumn{2}{|c|}{ Group B (400 pairs) } \\
\hline & ceftriaxone & $\begin{array}{l}\text { other } \\
\text { cephalosporins }\end{array}$ & ceftriaxone & penicillin \\
\hline Postoperative antibiotic therapy & $83(12.4)$ & $110(16.4)$ & $46(11.5)$ & $100(25.0)$ \\
\hline Mechanical ventilation & & & & \\
\hline (from 1st postoperative day) & $2(0.3)$ & $4(0.6)$ & 0 & $2(0.5)$ \\
\hline Reoperation & $34(3.6)$ & $26(3.9)$ & $9(2.3)$ & $14(3.5)$ \\
\hline Hospital stay (days) & 16.2 & 16.9 & 15.8 & $17.6^{*}$ \\
\hline
\end{tabular}

Figures in parentheses represent percentages. $* p<0.001$ for ceftriaxone versus penicillin. 
regimes confirmed the necessity of concomitant metronidazole with both cephalosporins and penicillin in elective colon surgery (table 11).

\section{Cost Effectiveness}

Differences in prophylactic efficacy are reflected in the incidence and severity of local and systemic postoperative infection, postoperative antibiotic requirements, admission to intensive care (with or without mechanical ventilation) and reoperation. The main differences found in the present study in the relationship between prophylactic regime and postoperative complications were in postoperative antibiotic requirements and duration of hospital stay (table 13). Ceftriaxone shortened hospital stay (by 0.7 days in group A, and by 1.8 days in group B). Using a daily rate of $€ 229.6$ for inpatients (general rate plus a $20 \%$ departmental rate in the surgical department of the Munich-Grosshadern Hospital, 1997), ceftriaxone saved $€ 160.7$ over other cephalosporins and $€ 413.2$ over penicillin. Although the cost of reoperation, an undoubtedly substantial factor, was not calculated due to the complexities involved, it was partly covered in costing the length of postoperative stay.

\section{Discussion and Conclusions}

The First (German) National Prevalence Study (NIDEP) showed that wound infection is only the third most common type of nosocomial infection (15.1\%) [1], preceded by infection of the urinary tract $(40.2 \%)$ and lower airways (19.7\%). Wound infection only becomes significant when it requires reoperation, as with deep-seated infection or abscess formation. Secondary systemic infection, on the other hand, almost always prolongs hospital stay. Postoperative pneumonia and septi- cemia always involve serious illness and increased mortality. Preoperative prophylaxis should thus aim at effective postoperative risk prevention by decreasing postoperative systemic complications as well as wound infection.

The risk of postoperative secondary infection does not end with the tying of the last suture. The risk of postoperative pneumonia increases with the duration of intubation anesthesia and postoperative ventilation. Many factors affect individual risk, e.g. pain, ileus and chronic lower airways disease. Urinary tract infection increases with postoperative retention or catheter drainage. Effective antibiotic levels thus need to be sustained over the early postoperative risk period to decrease complications, primarily systemic infection. The advantage of a long-acting cephalosporin such as ceftriaxone is that a single preoperative dose provides $24 \mathrm{~h}$ of cover. Prophylaxis with short-acting antibiotics, on the other hand, requires 2-3 doses over the same period. In addition to duration of activity, the microbiological spectrum is also an important consideration in selecting an antibiotic for visceral and abdominal surgery, which requires maximal cover against gramnegative bacteria, primarily E. coli, but also other Enterobacteriaceae. Third-generation cephalosporins have significant advantages in this regard over conventional cephalosporins and particularly over penicillin [2].

Our data do not indicate whether the greater efficacy of ceftriaxone (nonsignificant vs. other cephalosporins, significant vs. penicillin) was due to longer duration of activity and/ or a broader spectrum. The study was observational and comprised only a recommendation for $24 \mathrm{~h}$ of prophylaxis. The design left the choice of dosage to the physician. The efficacy of a single dose of ceftriaxone is probably due to the drug's specific pharmacokinetic profile, which ensures bactericidal concentra- 
Table 14. Wound infection rates and preoperative prophylaxis with different generations of cephalosporin [6]

\begin{tabular}{lc}
\hline Cephalosporin generation & $\begin{array}{l}\text { Wound infection } \\
\text { rate, } \%\end{array}$ \\
\hline First and second $(\mathrm{n}=1,079)$ & 14.8 \\
Third $(\mathrm{n}=340)$ & 7.9 \\
\hline
\end{tabular}

tions against susceptible organisms for $24 \mathrm{~h}$. In a report on the Dutch Trauma Trial, the authors noted that the mean serum concentration of $2 \mathrm{~g}$ of ceftriaxone $1 \mathrm{~h}$ after administration was $177 \mathrm{mg} / \mathrm{l}$ - well above the minimum inhibitory concentration for microorganisms causing infections in accident surgery [3]. Ceftriaxone also attains good tissue concentrations and can even demonstrate high bactericidal concentrations in bile in the case of cholestasis [4]. A matter for discussion is whether the tissue concentration in addition to the local concentration in the bowel might be effective in the prophylaxis of anastomosis insufficiency. An analogous mechanism has been demonstrated for preventing leakage of esophago-intestinal anastomosis [5].

A further result of our study is an overall view of the prophylactic regimes currently used for colon surgery in Germany. The treatment duration of ceftriaxone was only 1.5 days (median), compared to 2-3 days for the comparators (except amoxicillin/clavulanic acid). Its superiority is thus more likely to be due to a more potent spectrum than to a longer duration of activity.

A 1991 literature review [6] concluded that, at least in colon surgery, third-generation cephalosporins appeared to be clinically more effective than first- and second-generation cephalosporins, and thus display a better cost/ benefit ratio (table 14).
In a prospective randomized double-blind study of perioperative prophylaxis with ceftriaxone $2 \mathrm{~g} \pm$ metronidazole versus cefazolin $1 \mathrm{~g}+$ metronidazole in colorectal surgery [7], postoperative airway and urinary tract infections were more frequent with cefazolin $(\mathrm{p}<$ $0.01)$. All the deaths were in the cefazolin group, and all resulted from postoperative sepsis. Other studies have also reported greater efficacy with ceftriaxone in colon surgery [8-10]. In particular, a meta-analysis of 43 randomized comparative studies of perioperative prophylaxis with single-dose ceftriaxone versus other cephalosporins in a total of 13,482 patients found lower overall rates of infection with ceftriaxone - by $30 \%$ in wound infections, $47 \%$ in urinary tract infections and $19 \%$ in respiratory tract infections [11].

Our study did not address the impact of concomitant metronidazole. Although in one study, the authors concluded that it is not always necessary to give metronidazole in addition to ceftriaxone for perioperative prophylaxis [7], many authors have recommended this combination as advantageous $[8$, 9]. In the present study, metronidazole was combined with ceftriaxone in approximately $65 \%$ of cases, compared to $80 \%$ with other cephalosporins and only approximately 50\% with penicillin. The results of our risk analysis also confirm that metronidazole needs to be administered with all beta-lactams, since postoperative infectious complications were significantly reduced in each case.

Detailed studies have already shown that effective antibiotic prophylaxis not only enhances postoperative outcome but also substantially lowers costs $[12,13]$. It is thus not surprising that in our study, the greater overall efficacy of prophylaxis with ceftriaxone versus other beta-lactams in colon resection decreased costs by decreasing the postoperative infection rate. 


\section{References}

1 Rüden H, Gastmeier P, Daschner FD, Schumacher M: Nosocomial and community-acquired infections in Germany. Summary of the results of the First National Prevalence Study. Infection 1997;25:199-202.

2 Focht J, Nösner K: Empfindlichkeitsspektrum von Ceftriaxon und anderen Antibiotika. Krankenhauspharmazie 1997;11:531-534.

3 Boxma H, Broekhuizen T, Patka P, Oosting H: Randomised controlled trial of single-dose antibiotic prophylaxis in surgical treatment of closed fractures: The Dutch Trauma Trial. Lancet 1996;347:1133-1137.

4 Lippert H, Gastinger J: Antimicrobial prophylaxis in laparoscopic and conventional cholecystectomy. Conclusions of a large prospective multicenter quality assurance study in Germany. Chemotherapy 1998;44: 355-363.
5 Schardey HM, Kamps TH, Rau HG, Baretton G, Gatermann S, Exner H, Schildberg FW: Can oesophago-intestinal leakage develop in the complete absence of bacteria? A comparison of normal and germfree rats. Int J Surg SCI 1997;4:913.

6 Wittmann DH, Condon RE: Prophylaxis of postoperative infections. Infection 1991;19(suppl 6):S337S344.

7 Lumley JW, Siu SK, Pillay SP, Stitz R, Kemp RJ, Faoagali J, Nathanson LK, White S: Single dose ceftriaxone as prophylaxis for sepsis in colorectal surgery. Aust NZ J Surg 1992;62: 292-296.

8 Shepherd A, Roberts A, Ambrose NS: Ceftriaxone with metronidazole as single dose prophylaxis in colorectal surgery. Colo-proctology 1986;8:91-94.

9 Gastinger I, Lippert H, Winter M, Hell K: Antibiotikaanwendung bei der operativen Behandlung von 1,927 Patienten mit kolorektalem Karzinom. Coloproctology 1995;17: 18-26.
10 Mittelkötter U, Reith HB, Niemann M, Lee U, Kozuschek W: Effectiveness of different antibiotic prophylaxis on wound healing and hospital stay in colorectal surgery. Sixth Biennial Conference on Antiinfective Agents and Chemotherapy (BICON), May 2-4, 1996, Leipzig.

11 Bieser U, Dietrich ES, Frank U, Schwarzer G, Daschner F: Metaanalysis of the perioperative prophylaxis of ceftriaxone versus other cephalosporins. Fifth Annual Cochrane Colloquium, October 8-12, 1997, Amsterdam.

12 Lippert H, Gastinger I, Hell K: Wert einer effizienten Antibiotikaprophylaxe vor dem Hintergrund des neuen Gesundheitsstrukturgesetzes; in: Jahrbuch der Chirurgie. Zülpich, Biermann, 1996, pp 189-196.

13 Reers B, Hell-Türler K, Kullmann $\mathrm{KH}$ : Kosteneinsparungen mittels perioperativer Antibiotikaprophylaxe anhand einer Modellrechnung. ZAC 1996;14:233-236. 